\title{
A Comparative Study of Juvenile Nasal Angiofibroma with other Nasal Masses Presenting in a Tertiary Centre of Jharkhand
}

\author{
Dr. R.K.Pandey ${ }^{1}$,Dr.Ashit Toppo ${ }^{2}$,Dr.Nisha Shrivastava ${ }^{3}$ \\ Associate Professor ${ }^{1}$, Registrar ${ }^{2}$, Post Graduate ${ }^{3}$. \\ ${ }^{I}$ Dr. Ranbir Kumar Pandey With Designation Of Associate Professor, Department Of Ent, Rims, \\ Ranchi, Jharkhand, India. \\ ${ }^{2}$ Dr. Ashit Toppo With Designation Of Registrar, Department Of Ent, Rims, Ranchi, Jharkhand, India. \\ ${ }^{3}$ Dr. Nisha Shrivastava With Designation Of Junior Resident Academic, Department Of Ent, Rims, \\ Ranchi, Jharkhand, India.
}

\begin{abstract}
Introduction: Juvenile nasal angiofibromas (JNA) are benign tumours occurring in adolescent males. The aetiology of these masses has not been defined clearly. These stand apart of the sinonasal masses due to the high vascularity and non-encapsulated growth that might extend to the nasal cavity,nasopharynx, pterygopalatine fossa, infratemporal fossa, orbit, sphenoid sinus, and middle cranial fossa. ${ }^{1}$

Objectives: 1) To evaluate the percentage of JNA amongst all the nasal masses. 2) To categorisethe clinical features and socio-demographic profiles of JNA and other nasal masses.

Design of Study: Retrospective study.

Materials and Methods: The data for this study were collected from the admission register of ENT Department, RIMS, Ranchi during the period of July,2013 to December,2015. The total sample size for the study was 220. Templates were generated in MS Excel sheets and analysis was done using SSPS software (version 20).

Results: Following the data analysis we came to the conclusion that $4.1 \%$ of all the nasal mass operated in Department of ENT, RIMS were JNA. All the patients with JNA were males, below age of 20 years, mostly tribals (77.8\%) residing in rural areas (66.7\%) of Jharkhand. These were very much similar to the results we obtained upon analysis of the data for rest of the nasal masses. Most common presenting complaints due to JNA were recurrent epistaxis (88.9\%) and nasal obstruction (88.9\%) followed by nasal discharge (66.7\%), while for the other nasal masses the most common presenting complaints were nasal obstruction and nasal discharge.

Conclusion: Most of the male teenagers presenting with recurrent epistaxis with nasal obstruction turn out to be having a JNA.
\end{abstract}

Keywords: Juvenile nasal angiofibroma, nasal mass.

\section{Introduction}

Juvenile nasopharyngeal angiofibroma (JNA) accounts for $0.05 \%$ of all head and neck tumours. It is a rare, highly vascular nasopharyngeal mass. ${ }^{1}$ It occurs most often in male adolescents with an average age at diagnosis of 14-16 years. ${ }^{2-5}$ Even after this advancement of science, the exact nature of JNA is still unclear, the most accepted view currently as ahemangioma or vascular malformation. Beham et alsuggested that angiofibromas were vascular malformationson the basis of the various morphological irregularities they found in the vascular architecture of the tumor. ${ }^{6}$ Zhang et al.have reported data supporting the theory of JNA being anangiogenichistogenetic tumour and the hallmark of this lesion is uncontrolled vascular endothelial cell proliferation. $^{8}$

Seeing the occurrence of this tumour exclusively in male adolescents and the presence of androgen and estrogen receptors in JNA tissue, a hormone-dependent development was suggested. But this theory is still disputed as no alterations of serum hormonal levels were observed in the patients. ${ }^{9,10}$ The site of origin of the tumour is around pterygopalatine foramen, from where it might spread locally to the nasal cavity, pterygopalatine fossa, infratemporal fossa, orbit, or proceed intracranially. The tumour is clinically aggressive due to the vascular nature and expansive growth and invades locally, but histologically it is benign.

The diagnosis of JNA is based on the clinical history and proper examination of the patient, along with its radiological imaging. Nasal obstruction and recurrent epistaxis are the most common complaints of the patients presenting to the OPD. Diplopia, headache, rhinolaliaand hearing loss may occur if the disease spreads locally. On examination, a nasopharyngeal mass with a look standing apart from a nasal polyp is found, along with cheek and palate deformities, or proptosis. ${ }^{2,4}$ Surgical excision, with complete surgical removal is the treatment of choice for extracranial cases. ${ }^{2}$ Accurate preoperative evaluation of tumor extensions is very important for both the patient and the surgeon as it has a direct impact on surgical planning and results of treatment. 


\section{Materials And Methods}

This retrospective study included the patients with nasal masses admitted in Department of ENT, RIMS, Ranchi and operated during the period of July,2013 to December,2015. All of them were having a mass in nasal cavity confirmed by the CT scan report. All those with extensions beyond the pterygopalatine fossa or intracranially were excluded. The data were collected from the admission register, Department of ENT, RIMS, Ranchi and analysed using SSPS software (version 20).

\section{Results}

$4.1 \%$ of the nasal masses operated during the period of July,2013 to December,2015 were diagnosed as JNA. The categorisation of the patients on the basis of diagnosis of JNA is shown in Table 1.

Table 1. Categorisation on basis of diagnosis of JNA

\begin{tabular}{|l|l|l|}
\hline Diagnosis & $\begin{array}{l}\text { Frequency } \\
(\mathbf{n = 2 2 0})\end{array}$ & $\begin{array}{l}\text { Percentage } \\
(\boldsymbol{\%})\end{array}$ \\
\hline JNA & 9 & 4.1 \\
\hline Others & 211 & 95.9 \\
\hline
\end{tabular}

Out of the 9 cases of JNA, all were males below 20 years of age, most of which were tribals $(77.8 \%)$ from rural areas (66.7). The patients with other diagnoses included in the study were mostly males below 20 years of age, tribals from rural areas, same as that for JNA.

Table 2.shows the comparison of the socio-demographic profile of the nasal masses diagnosed as JNA with that of the rest of the nasal masses.

Table 2.Socio-demographic profiles of patients with JNA compared to other nasal masses.

\begin{tabular}{|c|c|c|c|c|c|c|}
\hline \multirow[t]{2}{*}{ Serial No. } & \multirow[t]{2}{*}{ Criteria } & \multirow[t]{2}{*}{ Groups } & \multicolumn{2}{|l|}{ JNA } & \multicolumn{2}{|l|}{ Others } \\
\hline & & & Frequency & $\begin{array}{l}\text { Percentage } \\
(\%)\end{array}$ & Frequency & $\begin{array}{l}\text { Percentage } \\
(\%)\end{array}$ \\
\hline \multirow[t]{3}{*}{1} & \multirow[t]{3}{*}{ Age } & $<10$ years & 1 & 11.1 & 104 & 49.3 \\
\hline & & $10-20$ years & 8 & 88.9 & 86 & 40.6 \\
\hline & & $>20$ years & 0 & 0 & 21 & 10.1 \\
\hline \multirow[t]{2}{*}{2} & \multirow[t]{2}{*}{ Sex } & Male & 9 & 100 & 146 & 69.2 \\
\hline & & Female & 0 & 0 & 65 & 30.8 \\
\hline \multirow[t]{2}{*}{3} & \multirow[t]{2}{*}{ Ethnicity } & Tribal & 7 & 77.8 & 156 & 73.9 \\
\hline & & Non-Tribal & 2 & 22.2 & 64 & 26.1 \\
\hline \multirow[t]{2}{*}{4} & \multirow[t]{2}{*}{ Residence } & Rural & 6 & 66.7 & 137 & 64.9 \\
\hline & & Urban & 3 & 33.3 & 83 & 35.1 \\
\hline
\end{tabular}

Patients with JNA had the most common complaint of recurrent nasal bleed (88.9\%) and ear ache (33.3) as a presenting complaint was more frequent than for the rest of the nasal masses, where nasal obstruction $(86.5 \%)$ was the most common complaint followed by nasal discharge(53.6\%). Graph 1 shows the comparison of the frequency of the presenting complaints of the patients with JNA to those with other type of nasal masses.

Graph 1.Comparison of clinical features as presenting complaint of JNA with other nasal masses.

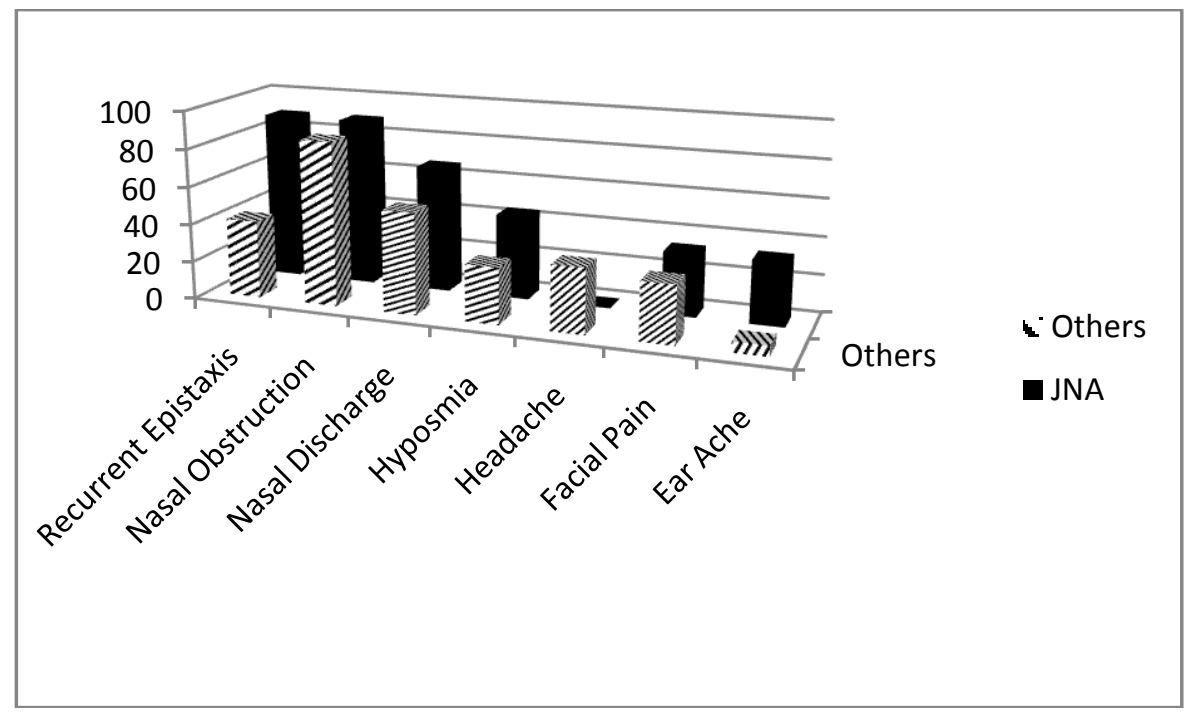




\section{Discussion}

In this study, $4.1 \%$ of all the cases of nasal masses were confirmed as JNA.Pradhanangaet al. ${ }^{11}$ reported 9 cases of angiofibroma over a period of two years in Nepal. Juvenile angiofibroma forms $0.5 \%$ of all head and neck tumours in Europe ${ }^{12}$.

All the cases diagnosed as JNA were males, while the male to female ratio for other nasal masses obtained was 2.25:1.The male-tofemale ratio of 1.7:1 was reported in the study on nasal masses by Zafaret al. ${ }^{13}$ All the patients with JNA were below 20 years of age while those with other masses had a mean age of 10-20 years. $73.9 \%$ of the patients with other nasal masses were tribals, mostly from rural areas of Jharkhand (64.95).The common presentations for JNA were recurrent epistaxis (88.9\%) and nasal obstruction (88.9\%), while those for the other nasal masses were nasal obstruction (86.5\%) and nasal discharge (53.6\%). Ear ache was more commonly associated with JNA (33.3\%) compared to the other masses $(5.6 \%)$. The results are in comparison with other studies. ${ }^{11,14}$

\section{Conclusion}

Masses in nasal cavity and nasopharynx are very common presentation in ENT OPD, RIMS. Our study showed that the nasal masses are common in $<20$ years age group and the patients are mostly tribals from rural areas. $4.1 \%$ of all these masses were diagnosed as JNA. Nasal obstruction was the most common presentation for sinonasal masses while recurrent epistaxis was for JNA. Complete surgical excision of all extracranial masses is the management of choice for all masses involving the nasal cavity and nasopharynx.

\section{Acknowledgements}

We are thankful to our faculty members and staffs of Medical Records Department, RIMS for their immense support.

\section{Funding}

No funding sources

\section{Conflict of Interest}

None

\section{Ethical Approval}

The study was approved by the Institutional Ethics Committee.

\section{References}

[1]. Batsakis JG. Tumors of the Head and Neck: Clinical and Pathological Considerations., 2nd edn. Baltimore, MD: Williams and Wilkins, 1974. , Google Scholar

[2]. Rekonnen S, Hagstrom J, Vuola J, .The changing surgical management of juvenile nasopharyngeal angiofibroma.Eur Arch Otorhinolaryngol 2011; 268: 599-607. , Google Scholar

[3]. Lloyd G, Howard D, Phelps P, . Juvenile angiofibroma: the lesson of 20 years of modern imaging. J LaryngolOtol 1999; 113: 127134. , Google Scholar

[4]. Hyun DW, Ryu JH, Kim YS, .Treatment outcomes of juvenile nasopharyngeal angiofibroma according to surgical approach.Int $\mathbf{J}$ PedOtorhinolaryngol 2011; 75: 69-73. , Google Scholar

[5]. Roche PH, Paris J, Regis J, . Management of invasive juvenile nasopharyngeal angiofibromas: the role of multimodality approach. Neurosurgery 2007; 61: 768-777. , Google Scholar

[6]. Beham A, Beham-Schmid C, Regauer S, . Nasopharyngeal angiofibroma: true neoplasm or vascular malformation? AdvAnatPathol 2000; 7: 36-46. , Google Scholar

[7]. Liang J, Yi Z, Lianq P. The nature of juvenile nasopharyngeal angiofibroma.Otolaryngol Head Neck Surg 2000; 123: 475-481. , Google Scholar Abstract

[8]. Zhang M, Sun X, Yu H, . Biological distinctions between juvenile nasopharyngeal angiofibroma and vascular malformation: an immunohistochemical study. ActaHistochemica 2011; 113: 626-630. , Google Scholar

[9]. Farag MM, Ghanimah SE, Ragaie A, .Hormonal receptors in juvenile nasopharyngeal angiofibroma.Laryngoscope 1987; 97: 208211. , Google Scholar

[10]. Saylam G, Yucel OT, Sungur A, .Proliferation, angiogenesis and hormonal markers in juvenile nasopharyngeal angiofibroma.Int J PediatrOtorhinolaryngol 2006; 70: 227-234. , Google Scholar

[11]. Pradhananga RB, Adhikari P, Thapa NM, et al. Overview of nasal masses. J Inst Med. 2008;30:13-16.

[12]. Lund VJ, Stammberger H, Nicolai P, et al. European position paper on endoscopic management of tumours of the nose, paranasal sinuses and skull base. Rhinology. 2010;48((Suppl 22)):1-143. [PubMed]

[13]. Zafar U, Khan N, Afroz N, et al. Clinicopathological study of non-neoplastic lesions of nasal cavity and paranasal sinuses. Indian J PatholMicrobiol. 2008;51:26-29. [PubMed]

[14]. Humayun AHM, ZahurulHuq AHM, Ahmed SMT, et al. Clinicopathological study of sinonasal masses. Bangladesh J Otorhinolaryngol. 2010;16:15-22. 